\title{
TCF4 and COL8A2 Gene Polymorphism Screening in a Greek Population of Late-onset Fuchs Endothelial Corneal Dystrophy
}

\author{
MARILITA M. MOSCHOS ${ }^{1}$, ANDRIANA DIAMANTOPOULOU ${ }^{2}$, \\ NIKOS GOULIOPOULOS ${ }^{1}$, KONSTANTINOS DROUTSAS ${ }^{1}$, ELENI BAGLI ${ }^{3}$, \\ KLIO CHATZISTEFANOU ${ }^{1}$, GEORGE KITSOS $^{3 *}$ and CHRISTOS KROUPIS ${ }^{2 *}$ \\ ${ }^{1}$ First Department of Ophthalmology, G. Gennimatas General Hospital, Medical School, \\ National and Kapodistrian University of Athens, Athens, Greece; \\ ${ }^{2}$ Department of Clinical Biochemistry, Attikon General Hospital, Medical School, \\ National and Kapodistrian University of Athens, Athens, Greece; \\ ${ }^{3}$ Department of Ophthalmology, Ioannina University General Hospital, University of Ioannina, Ioannina, Greece
}

\begin{abstract}
Background/Aim: Fuchs' endothelial corneal dystrophy (FECD) is a hereditary, progressive, bilateral, and irreversible disorder of the corneal endothelium. The purpose of this study was to develop a novel, accurate and highthroughput real-time polymerase chain reaction (PCR) method and melting-curve analysis in order to genotype the rs613872 polymorphism in the transcription factor 4 (TCF4) gene and to implement it on a well-ascertained sample of 22 Greek FECD patients and 58 healthy individuals, age- and sexmatched. Patients and Methods: DNA was extracted from blood samples, which were screened with the DNA sequencing method in order to detect the g.31753T>G/p.L450W (rs8035192) and g.31767C>A/p.Q455K (rs8035191) mutations in a COL8A2 genomic region. Results: TCF4 risk $G$ allele frequency increased to $48 \%$ in FECD patients compared to $17 \%$ in healthy-subjects $[O R=4.82(95 \% C I=1.98-11.73)]$. No p.L450W and p.Q455K COL8A2 gene mutations were detected. Conclusion: We confirmed that rs613872 in the TCF4 gene is strongly and statistically associated with late-onset FECD in a Greek population.
\end{abstract}

Fuchs' endothelial corneal dystrophy (FECD) is a hereditary, progressive, bilateral, and irreversible disorder of the corneal

This article is freely accessible online.

*These Authors contributed equally to this study.

Correspondence to: Marilita M. Moschos, MD, Ikarias 6, Ekali 14578, Greece. Tel: +30 6944887319, Fax: +30 2107768321, e-mail: moschosmarilita@yahoo.fr

Key Words: TCF4, COL8A2, polymorphism, Fuchs' endothelial corneal dystrophy. endothelium $(1,2)$. FECD is characterized by thickening of the Descemet's membrane and microscopic collagenous protuberances known as guttae (3). Progressive and accelerated loss of corneal endothelial cells and a concomitant increase in the extracellular matrix deposition at the level of Descemet's membrane take place, resulting in morphological changes in the size (polymegethism) and shape (pleomorphism) of the remaining endothelial cells $(4,5)$. As a consequence, the corneal endothelium is no longer able to support corneal deturgescence, leading to corneal edema, which causes the development of folds in Descemet's membrane, while increased endothelial pigmentation may also be present (4).

Patients initially complain of blurred vision (often worse in the morning), usually during the fourth and the fifth decade of their life. As the disease progresses, epithelial edema develops, leading to mycrocystic edema and epithelial bullae, which may rupture causing pain. Untreated cases of FECD often result in blindness (4). The only definitive treatment is corneal transplantation, either in the form of penetrating keratoplasty or Descemet's stripping endothelial keratoplasty $(6,7)$.

FECD is also the most common form of corneal dystrophies, being more frequent in women compared to men (2.5-3:1) (3, 8-12). The disease prevalence varies around the world and it is reported to affect $4 \%$ of the population over 40 years of age in the United States (13), whereas it is uncommon in Japan, Saudi Arabia, and in the Chinese of Singapore $(14,15)$.

The FECD grading scale, which was described and utilized by Krachmer, consists of 5 stages according to the number and distribution of guttae (13). More specifically, a severity score of 1 reflects minimal and asymptomatic disease and is defined as more than 12 central and scattered guttae; a cluster of central confluent guttae are scored as 2, and higher scores represent increasing diameters of distribution of confluent guttae (13). 
Based on the age of disease onset, FECD is divided into two categories, early- and late-onset. Early-onset FECD is rare, usually begins in the first decade of life, and becomes clinically detectable during the second and the third decade (4). Late-onset FECD is either sporadic or familial and is generally apparent in the fifth decade of life, progressing over the next two to three decades (8). It is a primarily autosomal-dominant condition (16-18), with incomplete penetrance $(13,19,20)$.

Although the exact etiology of FECD is still unclear, several studies suggested that FECD is a genetically heterogeneous disease associated with multiple genetic variations, which could be identified as possible contributors to its pathogenesis. Early-onset FECD has been associated with mutations in the collagen VIII $\alpha 2$ gene (COL8A2) (9, 21). Late-onset FECD is more genetically heterogeneous and several causal DNA mutations have been identified by the candidate-gene approach in families or by genome-wide association study (GWAS) in patients, in genes such as transcription factor 4 (TCF4), zinc finger E-box-binding homeobox 1 (ZEB1), ATP/GTP Binding Protein Like 1 $(A G B L 1)$, solute carrier family 4 sodium borate transporter member 11 (SLC4A11), and lipoxygenase homology domaincontaining 1 gene (LOXHD1) (21-24).

TCF4 gene is located on chromosome 18q (25), encodes a transcription factor protein E2-2, which is expressed in the cornea during development, and is involved in regulating cellular growth and differentiation (26). TCF4 gene mutations have been associated with several diseases, such as schizophrenia, primary sclerosing cholangitis and PittHopkins syndrome $(2,24)$. TCF4 polymorphisms have also attracted attention for their association with $\operatorname{FECD}(24,27)$. More specifically, it has been suggested by Baratz et al. that a significant association exists between FECD and four single nucleotide polymorphisms (SNPs) (rs17595731, rs613872, rs9954153, and rs2286812) of the TCF4 gene (2, 24). However, this suggestion was rejected by a study performed in India, underlying that differences in ethnic groups may affect this association (28).

The corneal endothelium secretes type VIII collagen (COL8), which is a significant component of normal Descemet's membrane. COL8 has two isoforms, a1 (COL8A1) and a2 (COL8A2), which interact to form a hexagonal lattice structure (29). The COL8A2 gene is located on chromosome $1 \mathrm{p}$ at position 34.3. As we previously mentioned, it is well established that mutations in the COL8A2 gene are linked with the development of early-onset FECD (30). The Gln455Lys (p.Q455K) missense mutation of COL8A2 gene, which encodes the $\alpha 2$ chain of type VIII collagen, involves replacement of highly conserved glutamine with negatively charged lysine, which may alter the tertiary structure of the protein. The Leu450Trp (p.L450W) mutation involves the substitution of leucine with tryptophan (4). These mutations result in abnormal intracellular accumulation of mutant COL8A peptides, affecting triple helical stability $(30,31)$, while they have been associated with posterior polymorphous dystrophy (32).

Based on the aforementioned observations, we investigated the possible associations between the rs613872 polymorphism of TCF4, and p.L450W and p.Q455K mutations or other polymorphisms in a COL8A2 genomic area, with late-onset FECD in a well-defined Greek population. To the best of our knowledge, our study is the first in the literature to conduct such genotyping in Greek patients with FECD.

\section{Materials and Methods}

Patients. The study was conducted on a cohort of 58 healthy controls (mean age $72 \pm 8$ years, $63.6 \%$ female) and 22 Greek patients with late-onset FECD (Krachmer scale $\geq 2$ ) (mean age $74 \pm 10$ years, $56.9 \%$ female), who were recruited during a 1 -year period (2016-2017). All participants were selected after ophthalmological evaluation and clinical data collection. Ophthalmological evaluation included visual acuity and slit-lamp anterior segment examination. Grading of disease severity was determined using a modified version of the Krachmer scale classification system, which classifies severity on a scale of 0 to 5 ; Grade 0: no central cornea guttae, grade 1: scattered central cornea guttae, grade 2: 1 or $2 \mathrm{~mm}$ of central cornea guttae, grade 3: 2 to 5 $\mathrm{mm}$ of grouped cornea guttae, grade $4: 5 \mathrm{~mm}$ of grouped central cornea guttae, grade 5: cornea guttae with corneal edema. Individuals were classified as being affected when the grade was 2 or more. The peripheral blood samples were obtained after approvals from the "G. Gennimatas" General Hospital Scientific and Bioethics committees and after obtaining signed informed consent from each participant.

Genomic DNA isolation. Blood samples were collected in EDTA tubes at "G. Gennimatas" General Hospital and stored at $-20^{\circ} \mathrm{C}$ until DNA extraction. Genomic DNA was extracted using a QIAamp DNA extraction kit (Qiagen, Hilden, Germany) according to the manufacturer's instructions. The absolute measurement of DNA concentration was calculated by the Quant-IT dsDNA BR Assay Kit in a Qubit fluorimeter (ThermoFisher Invitrogen, Waltham, MA, USA) which employs a dye specific for DNA. The DNA was stored at $-20^{\circ} \mathrm{C}$ until further use.

TCF4 (rs613872) novel real-time polymerase chain reaction (PCR) assay. In order to develop a novel, rapid and accurate, highthroughput TCF4 methodology for the rs613872 polymorphism, we selected the real-time PCR LightCycler instrument (Roche Applied Science, Penzberg, Germany) and the format of dual hybridization probes $(e . g$. anchor and sensor probes labeled with fluorescein and LC640 fluorescent dyes) that provides additional specificity (33). Only when both anchor and sensor probes locate their specific targets within the PCR product does fluorescence resonance energy transfer emission occur for the LC640 probe, which can then be continuously monitored in the F2 detection channel of the instrument. The sequences of the primers and hybridization probes for the proposed real-time PCR assay were designed in silico and 
Table I. Sequences of TCF4 primers and probes, COL8A2 primers and their corresponding Tm. The sensor probe aims at the mutant G allele and the underlined position pinpoints the position.

\begin{tabular}{llc}
\hline Name & Oligonucleotide sequence & Tm $\left({ }^{\circ} \mathrm{C}\right)$ \\
\hline Forward primer $T C F 4-\mathrm{F}$ & CTTGCCTCAGGGTATATAGCTGC & 57.9 \\
Reverse primer $T C F 4-\mathrm{R}$ & ATGGAAAACAAATCTCCCAGG & 56.2 \\
Sensor probe $T C F$ & GTGTCCAAACAATTTAACTTCTTTG-FL & 56.2 \\
Anchor probe $T C F 4$ & LC640-GCCTCTGTAAAATGGGAACAGTCAGGT & 64.0 \\
Forward primer $C O L 8 A 2-\mathrm{F}$ & GACCCCCTGGACCAACTG & 58.2 \\
Reverse primer $C O L 8 A 2-\mathrm{R}$ & GCGATGCCAGTCTCATCGAA & 59.4 \\
\hline
\end{tabular}

synthesized by TIB MolBiol (TIB Molbiol, Berlin, Germany) and are shown in Table I. The amplification reaction was carried out in glass capillaries (Roche Applied Science) and the $10 \mu \mathrm{l}$ total volume mixture consisted of $100 \mathrm{ng}$ genomic DNA as the template, $0.3 \mu \mathrm{l}$ TCF4-F $20 \mathrm{pmol} / \mu \mathrm{l}, 0.3 \mu \mathrm{l}$ TCF4-R $20 \mathrm{pmol} / \mu \mathrm{l}, 2.4 \mu$ moles each TCF4 sensor and anchor probe, $0.8 \mu$ of $25 \mathrm{mM} \mathrm{MgCl}_{2}$ (final optimal concentration $3 \mathrm{mM}$ ), $1 \mu \mathrm{l}$ of FastStart DNA MasterPlus Mix 10X (Roche Applied Science), and water to supplement up to $10 \mu$. After pre-incubation at $95^{\circ} \mathrm{C}$ for $10 \mathrm{~min}$ for hot-start activation of the polymerase enzyme, the three-step cycling protocol included 45 cycles of denaturation at $95^{\circ} \mathrm{C}$ for $10 \mathrm{sec}$, annealing at $59^{\circ} \mathrm{C}$ for $20 \mathrm{sec}$, and extension at $72^{\circ} \mathrm{C}$ for $20 \mathrm{sec}$. The temperature ramp rate was $20^{\circ} \mathrm{C} / \mathrm{sec}$.

Allele discrimination was achieved with melting-curve analysis of the PCR product after the cycling ended. The melting-curve analysis started by raising the temperature to $95^{\circ} \mathrm{C}$ for $1 \mathrm{~min}$, maintaining it at $43^{\circ} \mathrm{C}$ for $60 \mathrm{sec}$ and then proceeded with a slow heating step up to $80^{\circ} \mathrm{C}$ at a ramp rate of $0.4^{\circ} \mathrm{C} / \mathrm{sec}$. The first derivative plot of the collected fluorescent measurements $(-\mathrm{d}(\mathrm{F} 2) / \mathrm{dT} v s . \mathrm{T})$ was then used for the easy identification of wildtype and mutant alleles by their different melting temperature (Tm) peaks as the mismatched probe dehybridizes at an earlier stage (in our case, for the wild-type T allele).

A standard curve was created by using serial dilutions of a homozygous GG mutant, of known concentration (confirmed by DNA sequencing for accurate genotype). From various runs of the standard curves, cycle quantification $(\mathrm{Cq})$ of the standards and curve characteristics (slope and intercept) were collected and the coefficient of variation (CV\%) for the standards for within-run and between-run precision was estimated. The efficiency (E) of the realtime PCR assay was calculated with the equation $\mathrm{E}=10^{-1 / \mathrm{slope}}$ as previously described (34).

COL8A2 assay. A COL8A2 genomic region was screened using the DNA sequencing method in order to detect the g.31753T >G/p.L450W (rs8035192) and g.31767C >A/p.Q455K (rs8035191) COL8A2 mutations that are associated with early FECD, but also for other mutations or polymorphisms in the same area (sequences of the primer pair used are shown in Table I). The conventional PCR protocol was performed in $20 \mu$ l volumes containing genomic DNA (100 ng/ $\mu \mathrm{l}), 8$ pmoles COL8A2-F primer, 8 pmoles COL8A2-R primer, $10 \mu 1$ enzyme MyTaq $^{\text {TM }}$ Red Mix Bioline $2 \mathrm{X}, 2 \mu \mathrm{l}$ dimethyl sulfoxide, and water to supplement up to $20 \mu \mathrm{l}$. After an initial denaturation step at $95^{\circ} \mathrm{C}$ for $5 \mathrm{~min}, 40 \mathrm{PCR}$ cycles were performed as follows: $95^{\circ} \mathrm{C}$ for $30 \mathrm{sec}, 60^{\circ} \mathrm{C}$ for $30 \mathrm{sec}$, and $72^{\circ} \mathrm{C}$ for $1 \mathrm{~min}$, followed by a final extension at $72^{\circ} \mathrm{C}$ for $5 \mathrm{~min}$.
DNA sequencing. After purification of PCR amplicons (High Pure PCR Cleanup Micro kit; Roche Applied Science), cycle sequencing reaction was performed with the Big Dye 1.1 reagent (Applied Biosystems, Waltham, MA, USA) in both directions with the use of either the forward or the reverse primer, $10 \mu \mathrm{l}$ of the purified cycle sequencing reactions (by NucleoSeq columns; Macherey-Nagel, Germany) were heated at $95^{\circ} \mathrm{C}$ for 2 min and cooled immediately at $4^{\circ} \mathrm{C}$ for 2 min with $10 \mu \mathrm{l}$ formamide and then run in capillaries of an ABI Prism 310 Genetic Analyzer. For the analysis of DNA sequencing electropherograms, Chromas 2.01 software was used (Technelysium Pty Ltd, Australia) and results were compared with the expected gene sequences with NCBI BLAST.

Statistical analysis. Statistical analysis was performed using the SPSS 23.0 software package for Windows (IBM Armonk, NY, USA). The criterion used for statistical significance was $p<0.05$. Normality of distribution of age was assessed with the Kolmogorov-Smirnov test and the Shapiro-Wilk test. Median age between patients and controls was compared with the MannWhitney test and sex proportions with the Chi-squared test. Logistic regression analysis for FECD prediction was also performed. Conformance with Hardy-Weinberg equilibrium (HWE), allelic count, genotypic frequencies and odds ratio (OR) calculation with 95\% confidence intervals $(\mathrm{CI})$ were examined with the SNPstats software (35).

\section{Results}

TCF4 rs613872 real-time method validation. Our novel methodology was easy to perform and rapid (within $40 \mathrm{~min}$ after DNA isolation). The proper size (307 bp) and purity of the expected PCR product of the TCF4 assay was confirmed after inverting capillaries and $2 \%$ agarose electrophoresis of the collected amplicons. Characteristic melting curves for the TCF4 rs613872 SNP assay are shown in Figure 1. The peaks for the two alleles were clearly separated since the Tm was $56.14^{\circ} \mathrm{C}$ for the $\mathrm{T}$ allele $(\mathrm{SD}=0.99, \mathrm{CV}=1.7 \% \mathrm{n}=10)$ and $63.58^{\circ} \mathrm{C}$ for the $\mathrm{G}$ allele $(\mathrm{SD}=0.80, \mathrm{CV}=1.25 \% \mathrm{n}=8)$ and, therefore, $\Delta \mathrm{Tm}$ was $7.39^{\circ} \mathrm{C}(\mathrm{SD}=0.18, \mathrm{CV}=2.44 \% \mathrm{n}=6)$. The areas under the curve of the two allele melting peaks in the heterozygote samples were nearly equal, with a $\mathrm{G} / \mathrm{T}$ ratio of $0.982(\mathrm{SD}=0.078, \mathrm{CV}=7.9 \% \mathrm{n}=10)$. The method was accurate when compared to the gold standard method in 


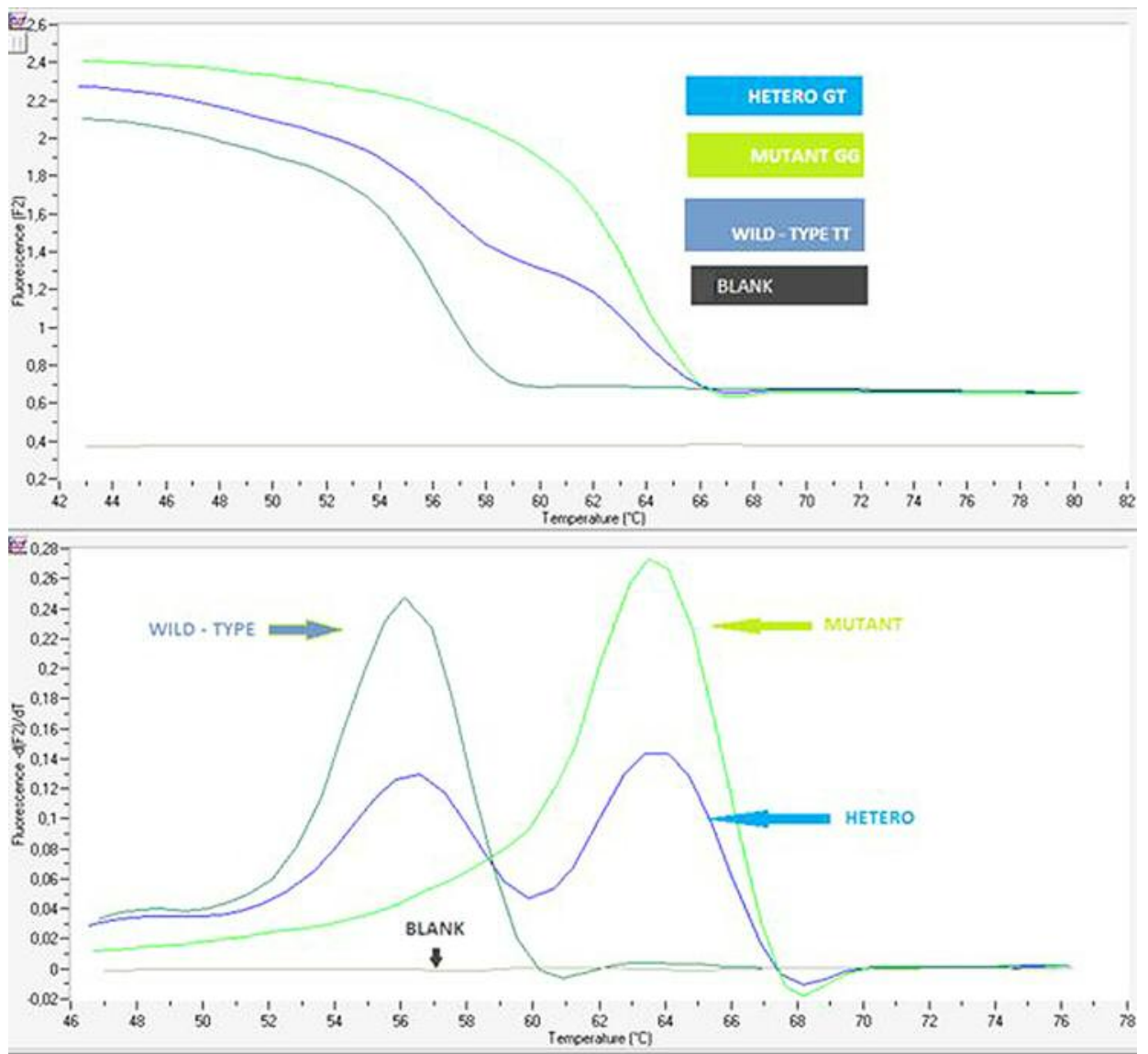

Figure 1. Representative melting curve and its first derivative from the TCF4 rs613872 assay in channel F2 for one heterozygous GT, one homozygous mutant $G G$, one wild-type TT and one blank sample.

genetic analysis: DNA sequencing (100\% concordance, Figure 2 for the forward primer). Reproducibility as judged from between-run precision and repeatability from withinrun precision were excellent (CVCq of the standards: $<1.2 \%$, $\mathrm{n}=8$ and $<1.9 \%, \mathrm{n}=3$ respectively). The method was linear: in a representative standard curve, the slope and intercept were -3.623 and 42.17 respectively, while the PCR reaction efficiency was calculated to be 1.86 (Figure 3 ).

TCF 4 results. TCF4 genotyping results were obtained from 22 patients with late-onset FECD and 58 healthy controls. Age (Mann-Whitney-test, $p>0.05$ ) and sex (Chi-squared test, $p>0.05$ ) did not differ significantly between the two groups. From the allelic count, the frequency of the risk G TCF4 allele of the rs613872 SNP increased significantly from $17 \%$ in controls to $48 \%$ in patient samples. All genotypic frequencies were in HWE equilibrium for both controls and patients $(p>0.05)$. In patients, 7 (31.8\%) wild-type TT were detected, 9 (40.9\%) GT heterozygotes, and 6 (27.3\%) homozygotes GG. Among the 58 healthy controls, 38
(65.5\%) were wild-type TT and $20(34.5 \%)$ were GT heterozygotes, while no homogeneous mutant GG was observed. According to SNPStats, both the dominant and the log-additive model were statistically significant models of inheritance; with the latter being the selected one since it possesses the least Akaike information criterion (AIC). This model estimates an $\mathrm{OR}=4.82(95 \% \mathrm{CI}=1.98-11.73)$ for $\mathrm{FECD}$ (Table II). When examining the effect of the presence of risk $\mathrm{G}$ allele along with age in binary logistic regression for FECD prediction, it was found that only the presence of $G$ allele remained a potent and independent predictive risk factor with $p=0.003$ and $\mathrm{OR}=5.98$ (95\%CI=1.82-19.60). The risk $\mathrm{G}$ allele constituted $56 \%$ of total TCF4 alleles in FECD men and only $46 \%$ of total TCF 4 alleles in women but this sex-specific trend did not reach statistical significance.

COL8A2 results. No individuals with COL8A2 g.31753T >G/p.L450W (rs8035192) or g.31767C >A p.Q455K (rs8035191) were detected in our late-onset FECD population, as expected. However, two sequence changes were detected in 


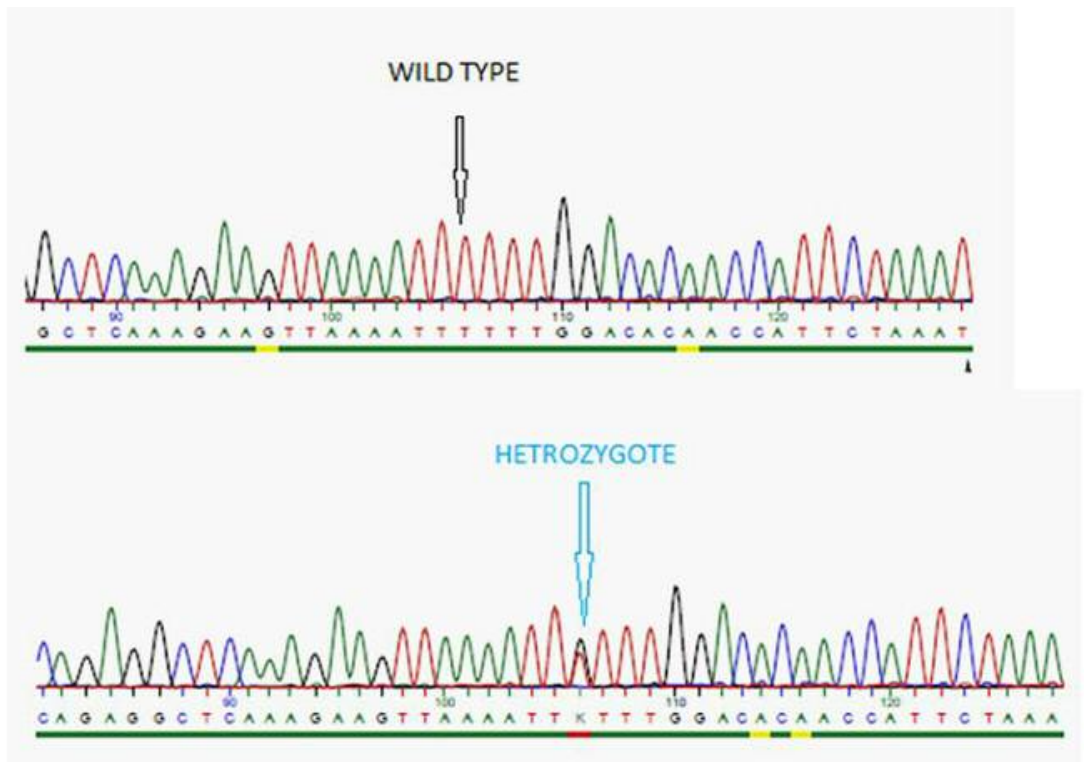

HOMOZYGOTE

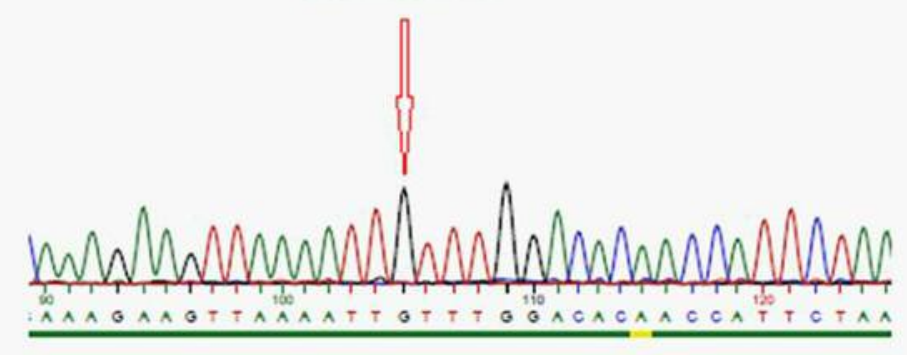

Figure 2. DNA sequencing analysis of a wild-type TT, a heterozygote TG, and a mutant homozygote GG in the TCF4 gene rs613872 SNP area (forward primer TCF4-F).

a 78-year-old patient with FECD: a silent one (NM_005 202.3:c1526C $>\mathrm{A} \rightarrow$ p.P508P, reported previously as rs560539803 with minor allelic frequency MAF 0.0004) and one novel missense (NM_005202.3:c1491G >A $\rightarrow$ p.A497T) (Figure 4). This amino acid change from alanine to threonine was examined in online prediction programs (PMut, Mutationt@sting, Provean) to determine whether it might cause damaging changes in the structure and function of the COL8A2 protein; however, it was considered benign or tolerated.

\section{Discussion}

As we previously mentioned, the exact etiology of late-onset FECD still remains obscure. The theory of a genetic influence on FECD development is well established, while the role of several gene mutations has been evaluated by multiple studies. We aimed to determine whether gene polymorphisms of TCF4 (rs613872) and COL8A2 [g.31753T>G/p.L450W (rs8035192) and g.31767C >A/p.Q455K (rs8035191) mutations] are associated with late-onset FECD in a wellascertained Greek population.

Initially, we developed and validated an accurate (100\% concordance with DNA sequencing), linear, reproducible and fast methodology ( $<1 \mathrm{~h}$ after DNA extraction of 32 samples) for TCF4 genotyping in the LightCycler platform. Considering the effect size of the polymorphism and the frequency of the disease, it is our belief that soon this assay could be transferred to the higher throughput LC480 or LC1536 instruments. There, a significantly larger number of samples could be accommodated (up to 1,536), and this assay can find its place in clinical (patient population screening) as well as research applications. We 


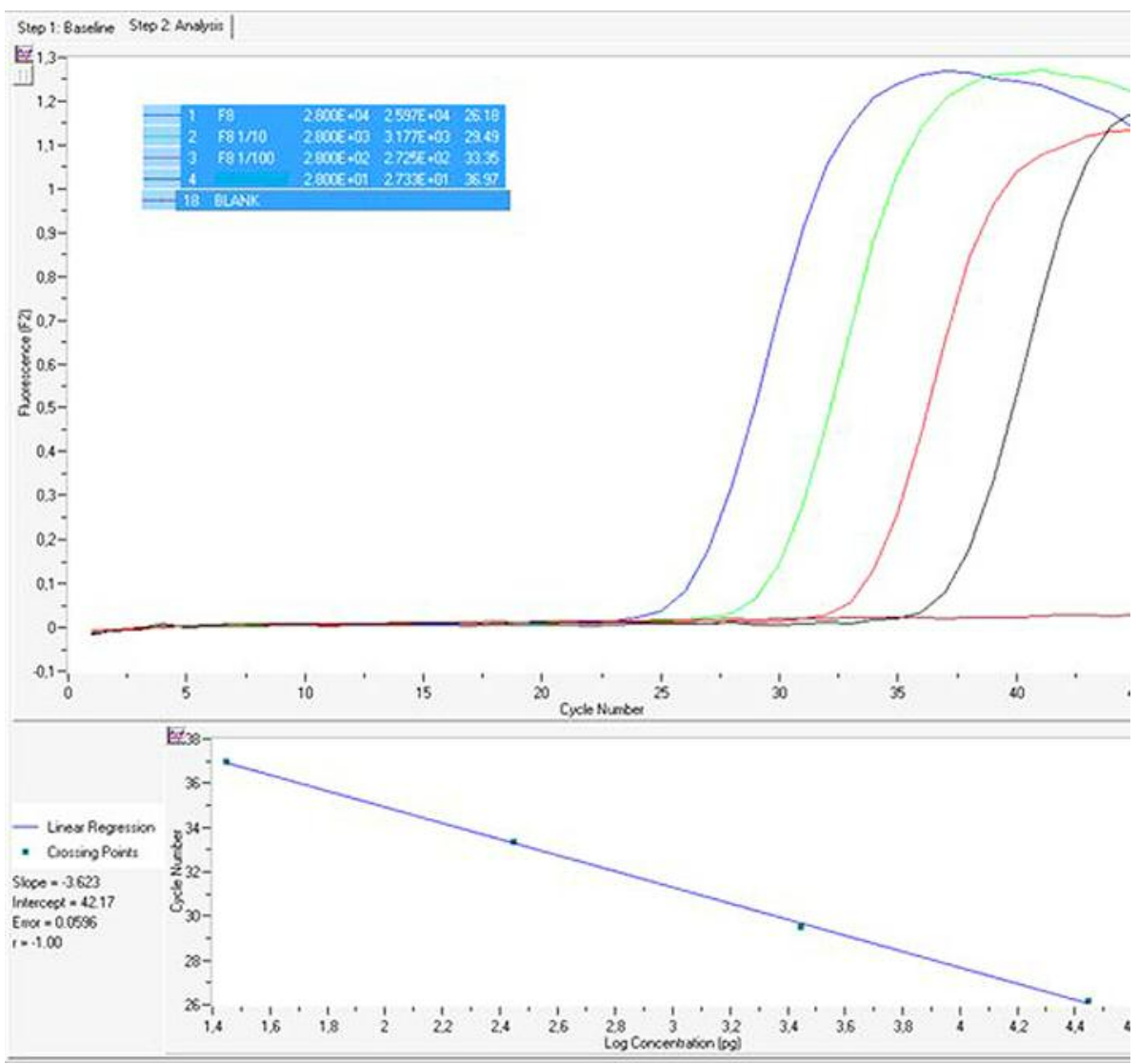

Figure 3. Representative standard curve for the rs613872 real-time PCR TCF4 assay in the LightCycler. Different concentrations of a quantitated DNA standard were used ranging from $28 \times 10^{1}$ to $28 \times 10^{5} \mathrm{pg}$ DNA per reaction and Cqs were recorded and the calibration plot was calculated with linear regression from the LightCycler software.

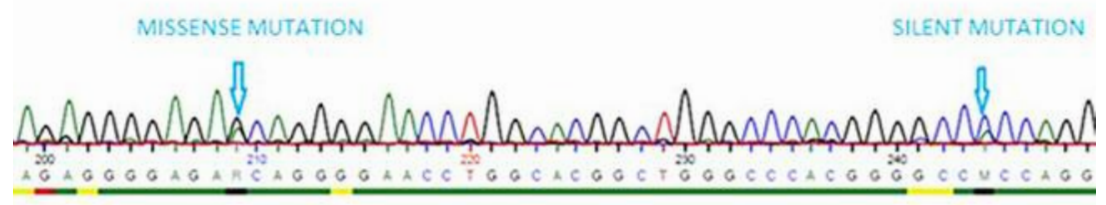

Figure 4. DNA sequencing analysis of a 78-year-old patient with FECD: wild-type GG and AA for COL8A2 gene rs80358192 and 80358191 SNPs but with a silent (NM_005202.3:c1526C>A $\rightarrow$ p.P508P) and a novel missense COL8A2 mutation (NM_005202.3:c1491G>A $\rightarrow p . A 497 T$, using the forward primer COL8A2-F).

demonstrated that TCF4 rs613872 GT and GG genotypes are positively and strongly associated with late-onset FECD in a Greek cohort of patients. Our findings suggest that a selective link exists between the presence of a $\mathrm{G}$ allele at rs613872 in TCF4 gene and late-onset FECD, since the carriers of a $\mathrm{G}$ allele are almost five times more likely to develop the disease compared to individuals with the wildtype TT genotype. Our findings support recent studies reporting that rs613872 polymorphism in the TCF4 gene is strongly associated with FECD $(24,36)$ and suggesting that TCF4 polymorphisms contribute to FECD pathogenesis. However, this association is not present in every ethnic group, since this association was rejected in a cohort of patients in India (28), while this polymorphism was not detected in Chinese patients with FECD (37). To the best of our knowledge, this is the first time that this polymorphism has been studied in relation to FECD in a Greek population. 
Table II. Genotypic frequencies, inheritance models, and calculated ORs for the rs613872 SNP in the TCF4 gene from the SNPStats software.

\begin{tabular}{|c|c|c|c|c|c|c|}
\hline Model & Genotype & Controls & Patients with FECD & OR $(95 \% \mathrm{CI})$ & $p$-Value & AIC \\
\hline \multirow[t]{3}{*}{ Codominant } & $\mathrm{T} / \mathrm{T}$ & $38(65.5 \%)$ & $7(31.8 \%)$ & 1.00 & NA & 80.8 \\
\hline & $\mathrm{G} / \mathrm{T}$ & $20(34.5 \%)$ & $9(40.9 \%)$ & $2.44(0.79-7.54)$ & & \\
\hline & $\mathrm{G} / \mathrm{G}$ & $0(0 \%)$ & $6(27.3 \%)$ & NA (0.00-NA) & & \\
\hline \multirow[t]{2}{*}{ Dominant } & $\mathrm{T} / \mathrm{T}$ & $38(65.5 \%)$ & $7(31.8 \%)$ & 1.00 & 0.0065 & 90.7 \\
\hline & G/T-G/G & $20(34.5 \%)$ & $15(68.2 \%)$ & $4.07(1.43-11.61)$ & & \\
\hline \multirow[t]{2}{*}{ Recessive } & T/T-G/T & $58(100 \%)$ & $16(72.7 \%)$ & 1.00 & NA & 81.3 \\
\hline & $\mathrm{G} / \mathrm{G}$ & $0(0 \%)$ & $6(27.3 \%)$ & NA (0.00-NA) & & \\
\hline \multirow[t]{2}{*}{ Overdominant } & T/T-G/G & $38(65.5 \%)$ & $13(59.1 \%)$ & 1.00 & 0.6 & 97.8 \\
\hline & $\mathrm{G} / \mathrm{T}$ & $20(34.5 \%)$ & $9(40.9 \%)$ & $1.32(0.48-3.60)$ & & \\
\hline Log-additive & N/A & N/A & N/A & $4.82(1.98-11.73)$ & $1 \mathrm{e}-04$ & 83.5 \\
\hline
\end{tabular}

T: Wild-type allele; G: risk-mutant allele; AIC: Akaike information criterion; FECD: Fuchs Endothelial Corneal Dystrophy; CI: confidence interval; OR: odds ratio; SNP: single-nucleotide polymorphism; N/A: not applicable. Bold values indicate statistically significant correlations.

The TCF4 gene encodes the E2-2 protein, a member of the ubiquitously expressed class I basic helix-loop-helix transcription factors, which are implicated in cellular growth and differentiation (37). E2-2 protein is expressed in developing corneal endothelium and is involved in endothelium growth, proliferation, and differentiation (38). Mutations in TCF4 gene result in dysfunction of E2-2 protein, and as a consequence the number of endothelial cells is decreased, a situation which is observed in FECD (24). Furthermore, E2-2 protein up-regulates the expression of zinc finger E-box binding homeobox 1 (ZEB1) protein. ZEB1 protein binds to E-box promoters and is implicated in epithelial-to-mesenchymal transition (EMT), through the repression of E-cadherin (39). Through these mechanisms, ZEB1 protein has been identified as the pathogenic protein of FECD (2). Taking the aforementioned proofs into consideration, it has been suggested that mutations in the TCF4 gene, with the rs613872 polymorphism being one of the most prominent, significantly elevate the risk for the development of late-onset FECD. In our study, risk TCF4 allele was detected more frequently in men with FECD compared to women, however, this sex-specific trend did not reach statistical significance, most probably due to the limited sample number of our cohort. In the largest GWAS study to date on FECD, another TCF4 polymorphism (rs784277) conferred a significantly higher risk for FECD development on men $(\mathrm{OR}=7.56,95 \% \mathrm{CI}=5.96-$ 9.57) compared to women (OR=5.06, 95\% CI=4.29-5.96) (40).

Another TCF4 polymorphism frequently assessed in various FECD populations is a trinucleotide repeat -termed as CTG18.1- which is deleterious when present in above 40 repetitions, probably due to either RNA toxicity or toxic dipeptide formation, an analogous situation to $C 9$ orf72 repeats for frontotemporal dementia (41). This polymorphism, in general, confers greater risk $(\mathrm{OR}=32.3,95 \% \mathrm{CI}=13.4-77.6)$ compared to the aforementioned rs613872 TCF4 SNP. The two polymorphisms are in significant linkage disequilibrium $\left(r^{2}=0.47\right)$, but still far from absolute; therefore, testing for both is warranted in patients with FECD in order to detect all cases that might be attributed to the TCF4 gene $(40,42,43)$.

We did not detect COL8A2 g.31753T $>$ G/p.L450W (rs8035192) nor g.31767C >A/p.Q455K (rs8035191) polymorphisms in the study population of patients with lateonset FECD. Although these two mutations are wellestablished risk factors for the development of early-onset FECD (4), no role for them has been recognized in the development of the much more frequent late-onset FECD (4).

Both these mutations affect the triple helical stability of COL8 through the abnormal accumulation of mutant COL8 peptides $(30,31)$. Chronic intracellular accumulation of COL8 is likely to be injurious to the fragile corneal endothelium and the unfolded protein stress response and increased endothelial cell apoptosis have been noted in patients with FECD (44-47). Although the pathological mechanisms of both early- and late-onset FECD are similar, including progressive loss of endothelial cells associated with characteristic excrescences and thickening of Descemet's membrane, COL8A2 g.31753T>G/p.L450W (rs8035192) and g.31767C>A/p.Q455K (rs8035191) polymorphisms have been associated only with early-onset FECD.

Transparency of the human cornea is necessary for vision. FECD is usually a bilateral, heritable degeneration of the corneal endothelium, and a leading indication for corneal transplantation in developed countries. While the early-onset, and rarer, form of FECD has been linked to COL8A2 mutations, the more common, late-onset form of FECD has genetic mutations linked to only a minority of cases. It is therefore important to identify the genetic background of patients suffering from FECD in order to better understand the importance of clinical findings, their onset and their progression.

In conclusion, in our study of a Greek population, the rs613872 SNP in TCF4 gene was confirmed to be strongly and statistically associated with late-onset FECD. It was also confirmed that the early-onset causative p.L450W and 
p.Q455K COL8A2 gene mutations are not associated with late-onset FECD. A potential limitation of this study is its relatively small sample size.

Certainly, in the future, with the advent of next-generation sequencing methods, we could expand our genetic testing to other implicated genes (ZEB1, AGBL1, SLC4A11, and $L O X L H D 1$ ) that can be assessed simultaneously in a large number of DNA samples suitably-barcoded. In the most recent and largest of all FECD GWAS studies involving 2,075 patients and 3,342 controls of Caucasian descent, besides the confirmation of the aforementioned gene associations, another three gene associations were detected in $\mathrm{KN}$ motifand ankyrin repeat domain-containing protein 4 (KANK4), laminin gamma 1 ( $L A M C 1)$ and $\mathrm{Na}^{+} / \mathrm{K}^{+}$transporting ATPase, beta-1 polypeptide $(A T P 1 B 1)$ when a $p$-value significance threshold was set at $10^{-7}(40)$. These latest findings could also be included in future studies in order to detect the full spectrum of genes attributing to late-onset FECD.

\section{Conflicts of Interest}

No potential conflict of interest in regard to this study was reported by the Authors.

\section{Authors' Contributions}

MMM wrote and reviewed the manuscript. AD did the experimental (lab) work, performed the statistical analysis and wrote the manuscript. NG performed the statistical analysis and wrote the manuscript. $\mathrm{KD}, \mathrm{EB}, \mathrm{KC}$, and $\mathrm{GK}$ collected data and reviewed the manuscript. CK selected the genes to be analyzed, designed the experimental work, wrote and reviewed the manuscript.

\section{References}

1 Fuchs E: Dystrophia epithelialis corneae. Graefes Arch Clin Exp Ophthalmol 76: 478-508, 1910.

2 Li D, Peng X and Sun H: Association of TCF4 polymorphisms and Fuchs' endothelial dystrophy: a meta-analysis. BMC Ophthalmol 15: 61, 2015. PMID: 26087656. DOI: 10.1186/s 12886-015-0055-6

3 Waring GO, III, Bourne WM, Edelhauser HF and Kenyon KR: The corneal endothelium. Normal and pathologic structure and function. Ophthalmology 89: 531-590, 1982. PMID: 7122038.

4 Elhalis H, Azizi B and Jurkunas UV: Fuchs endothelial corneal dystrophy. Ocul Surf 8: 173-184, 2010. PMID: 20964980.

5 Hamill CE, Schmedt T and Jurkunas U: Fuchs endothelial cornea dystrophy: a review of the genetics behind disease development. Semin Ophthalmol 28: 281-286, 2013. PMID: 24138036. DOI: $10.3109 / 08820538.2013 .825283$

6 Dobbins KR, Price FW Jr. and Whitson WE: Trends in the indications for penetrating keratoplasty in the midwestern United States. Cornea 19: 813-816, 2000. PMID: 11095055.

7 Darlington JK, Adrean SD and Schwab IR: Trends of penetrating keratoplasty in the United States from 1980 to 2004. Ophthalmology 113: 2171-2175, 2006. PMID: 16996602.

8 Wilson SE and Bourne WM: Fuchs' dystrophy. Cornea 7: 2-18, 1988. PMID: 3280235.
9 Biswas S, Munier FL, Yardley J, Hart-Holden N, Perveen R, Cousin P, Sutphin JE, Noble B, Batterbury M, Kielty C, Hackett A, Bonshek R, Ridgway A, McLeod D, Sheffield VC, Stone EM, Schorderet DF and Black GC: Missense mutations in COL8A2, the gene encoding the alpha2 chain of type VIII collagen, cause two forms of corneal endothelial dystrophy. Hum Mol Genet 10: 2415-2423, 2001. PMID: 11689488.

10 Shuttleworth CA: Type VIII collagen. Int J Biochem Cell Biol 29: 1145-1148, 1997. PMID: 9438378.

11 Stephan S, Sherratt MJ, Hodson N, Shuttleworth CA and Kielty $\mathrm{CM}$ : Expression and supramolecular assembly of recombinant alpha1(viii) and alpha2(viii) collagen homotrimers. J Biol Chem 279: 21469-21477, 2004. PMID: 14990571. DOI: 10.1074/ jbc.M305805200

12 Jun AS, Meng H, Ramanan N, Matthaei M, Chakravarti S, Bonshek R, Black GC, Grebe R and Kimos M: An alpha 2 collagen VIII transgenic knock-in mouse model of Fuchs endothelial corneal dystrophy shows early endothelial cell unfolded protein response and apoptosis. Hum Mol Genet 21: 384-393, 2012. PMID: 22002996. DOI: $10.1093 / \mathrm{hmg} / \mathrm{ddr} 473$

13 Krachmer JH, Purcell JJ Jr., Young CW and Bucher KD: Corneal endothelial dystrophy. A study of 64 families. Arch Ophthalmol 96: 2036-2039, 1978. PMID: 309758.

14 Santo RM, Yamaguchi T, Kanai A, Okisaka S and Nakajima A: Clinical and histopathologic features of corneal dystrophies in Japan. Ophthalmology 102: 557-567, 1995. PMID: 7724173.

15 Vithana EN, Morgan PE, Ramprasad V, Tan DT, Yong VH, Venkataraman D, Venkatraman A, Yam GH, Nagasamy S, Law RW, Rajagopal R, Pang CP, Kumaramanickevel G, Casey JR and Aung T: SLC4A11 mutations in Fuchs endothelial corneal dystrophy. Hum Mol Genet 17: 656-666, 2008. PMID: 18024964. DOI: $10.1093 / \mathrm{hmg} / \mathrm{ddm} 337$

16 Cross HE, Maumenee AE and Cantolino SJ: Inheritance of Fuchs' endothelial dystrophy. Arch Ophthalmol 85: 268-272, 1971. PMID: 5313141.

17 Rosenblum P, Stark WJ, Maumenee IH, Hirst LW and Maumenee AE: Hereditary Fuchs' Dystrophy. Am J Ophthalmol 90: 455-562, 1980. PMID: 6968504.

18 Magovern M, Beauchamp GR, McTigue JW, Fine BS and Baumiller RC: Inheritance of Fuchs' combined dystrophy. Ophthalmology 86: 1897-1923, 1979. PMID: 399801.

19 Gottsch JD, Sundin OH, Liu SH, Jun AS, Broman KW, Stark WJ, Vito EC, Narang AK, Thompson JM and Magovern M: Inheritance of a novel COL8A2 mutation defines a distinct early-onset subtype of fuchs corneal dystrophy. Invest Ophthalmol Vis Sci 46: 1934-1939, 2005. PMID: 15914606. DOI: $10.1167 /$ iovs.04-0937

20 Sundin OH, Jun AS, Broman KW, Liu SH, Sheehan SE, Vito EC, Stark WJ and Gottsch JD: Linkage of late-onset Fuchs corneal dystrophy to a novel locus at 13pTel-13q12.13. Invest Ophthalmol Vis Sci 47: 140-145, 2006. PMID: 16384955. DOI: 10.1167/iovs.05-0578

21 Riazuddin SA, Vithana EN, Seet LF, Liu Y, Al-Saif A, Koh LW, Heng YM, Aung T, Meadows DN, Eghrari AO, Gottsch JD and Katsanis N: Missense mutations in the sodium borate cotransporter SLC4A11 cause late-onset Fuchs corneal dystrophy. Hum Mutat 31: 1261-1268, 2010. PMID: 20848555. DOI: $10.1002 /$ humu.21356

22 Riazuddin SA, Parker DS, McGlumphy EJ, Oh EC, Iliff BW, Schmedt T, Jurkunas U, Schleif R, Katsanis N and Gottsch JD: 
Mutations in LOXHD1, a recessive-deafness locus, cause dominant late-onset Fuchs corneal dystrophy. Am J Hum Genet 90: 533-539, 2012. PMID: 22341973. DOI: 10.1016/ j.ajhg.2012.01.013

23 Forrest MP, Hill MJ, Quantock AJ, Martin-Rendon E and Blake DJ: The emerging roles of TCF4 in disease and development. Trends Mol Med 20: 322-331, 2014. PMID: 24594265. DOI: 10.1016/j.molmed.2014.01.010

24 Baratz KH, Tosakulwong N, Ryu E, Brown WL, Branham K, Chen W, Tran KD, Schmid-Kubista KE, Heckenlively JR, Swaroop A, Abecasis G, Bailey KR and Edwards AO: E2-2 protein and Fuchs's corneal dystrophy. N Engl J Med 363: 10161024, 2010. PMID: 20825314. DOI: 10.1056/NEJMoa1007064

25 Sundin OH, Broman KW, Chang HH, Vito EC, Stark WJ and Gottsch JD: A common locus for late-onset Fuchs corneal dystrophy maps to 18q21.2-q21.32. Invest Ophthalmol Vis Sci 47: 3919-3926, 2006. PMID: 16936105. DOI: 10.1167/iovs.05-1619

26 Murre C, Bain G, van Dijk MA, Engel I, Furnari BA, Massari ME, Matthews JR, Quong MW, Rivera RR and Stuiver MH: Structure and function of helix-loop-helix proteins. Biochim Biophys Acta 1218: 129-135, 1994. PMID: 8018712

27 Sullivan PF, Daly MJ and O'Donovan M: Genetic architectures of psychiatric disorders: the emerging picture and its implications. Nat Rev Genet 13: 537-551, 2012. PMID: 22777127. DOI: $10.1038 / \operatorname{nrg} 3240$

28 Nanda GG, Padhy B, Samal S, Das S and Alone DP: Genetic association of TCF4 intronic polymorphisms, CTG18.1 and rs17089887, with Fuchs' endothelial corneal dystrophy in an Indian population. Invest Ophthalmol Vis Sci 55: 7674-7680, 2014. PMID: 25342617. DOI: 10.1167/iovs.14-15297

29 Sawada H, Konomi H and Hirosawa K: Characterization of the collagen in the hexagonal lattice of Descemet's membrane: its relation to type VIII collagen. J Cell Biol 110: 219-227, 1990. PMID: 2104858.

30 Kelliher C, Chakravarti S, Vij N, Mazur S, Stahl PJ, Engler C, Matthaei M, Yu SM and Jun AS: A cellular model for the investigation of Fuchs' endothelial corneal dystrophy. Exp Eye Res 93: 880-888, 2011. PMID: 22020132. DOI: 10.1016/ j.exer.2011.10.001.

31 Levy SG, Moss J, Sawada H, Dopping-Hepenstal PJ and McCartney AC: The composition of wide-spaced collagen in normal and diseased Descemet's membrane. Curr Eye Res 15: 45-52, 1996. PMID: 8631203.

32 Vedana G, Villarreal G, Jr. and Jun AS: Fuchs endothelial corneal dystrophy: current perspectives. Clin Ophthalmol 10: 321-330, 2016. PMID: 26937169. DOI: 10.2147/OPTH.S83467

33 Chiras D, Tzika K, Kokotas H, Oliveira SC, Grigoriadou M, Kastania A, Dima K, Stefaniotou M, Aspiotis M, Petersen MB, Kroupis C and Kitsos G: Development of novel LOXL1 genotyping method and evaluation of LOXL1, APOE and MTHFR polymorphisms in exfoliation syndrome/glaucoma in a Greek population. Mol Vis 19: 1006-1016, 2013. PMID: 23687437.

34 Velissari A, Skalidakis I, Oliveira SC, Koutsandrea C, Kitsos G, Petersen MB and Kroupis C: Novel association of FCGR2A polymorphism with age-related macular degeneration (AMD) and development of a novel CFH real-time genotyping method. Clin Chem Lab Med 53: 1521-1529, 2015. PMID: 25811666. DOI: $10.1515 / \mathrm{cclm}-2014-0920$

35 Sole X, Guino E, Valls J, Iniesta R and Moreno V: SNPStats: a web tool for the analysis of association studies. Bioinformatics 22: 19281929, 2006. PMID: 16720584. DOI: 10.1093/ bioinformatics/btl268
36 Riazuddin SA, McGlumphy EJ, Yeo WS, Wang J, Katsanis N and Gottsch JD: Replication of the TCF4 intronic variant in lateonset Fuchs corneal dystrophy and evidence of independence from the FCD2 locus. Invest Ophthalmol Vis Sci 52: 2825-2829, 2011. PMID: 21245398. DOI: 10.1167/iovs.10-6497

37 Thalamuthu A, Khor CC, Venkataraman D, Koh LW, Tan DT, Aung T, Mehta JS and Vithana EN: Association of TCF4 gene polymorphisms with Fuchs' corneal dystrophy in the Chinese. Invest Ophthalmol Vis Sci 52: 5573-5578, 2011. PMID: 21659310. DOI: $10.1167 /$ iovs.11-7568

38 Wright AF and Dhillon B: Major progress in Fuchs's corneal dystrophy. N Engl J Med 363: 1072-1075, 2010. PMID: 20825321. DOI: 10.1056/NEJMe1007495

39 Eger A, Aigner K, Sonderegger S, Dampier B, Oehler S, Schreiber M, Berx G, Cano A, Beug H and Foisner R: DeltaEF1 is a transcriptional repressor of E-cadherin and regulates epithelial plasticity in breast cancer cells. Oncogene 24: 23752385, 2005. PMID: 15674322. DOI: 10.1038/sj.onc.1208429

40 Afshari NA, Igo RP, Jr., Morris NJ, Stambolian D, Sharma S, Pulagam VL, Dunn S, Stamler JF, Truitt BJ, Rimmler J, Kuot A, Croasdale CR, Qin X, Burdon KP, Riazuddin SA, Mills R, Klebe S, Minear MA, Zhao J, Balajonda E, Rosenwasser GO, Baratz KH, Mootha VV, Patel SV, Gregory SG, Bailey-Wilson JE, Price MO, Price FW, Jr., Craig JE, Fingert JH, Gottsch JD, Aldave AJ, Klintworth GK, Lass JH, Li YJ and Iyengar SK: Genome-wide association study identifies three novel loci in Fuchs endothelial corneal dystrophy. Nat Commun 8: 14898, 2017. PMID: 28358029. DOI: $10.1038 /$ ncomms 14898

41 Taylor JP, Brown RH, Jr. and Cleveland DW: Decoding ALS: From genes to mechanism. Nature 539: 197-206, 2016. PMID: 27830784. DOI: $10.1038 /$ nature20413

42 Mootha VV, Hussain I, Cunnusamy K, Graham E, Gong X, Neelam S, Xing C, Kittler R and Petroll WM: TCF4 triplet repeat expansion and nuclear RNA foci in fuchs' endothelial corneal dystrophy. Invest Ophthalmol Vis Sci 56: 2003-2011, 2015. PMID: 25722209. DOI: 10.1167/iovs.14-16222

43 Wieben ED, Aleff RA, Tosakulwong N, Butz ML, Highsmith WE, Edwards AO and Baratz KH: A common trinucleotide repeat expansion within the transcription factor 4 (TCF4, E2-2) gene predicts Fuchs corneal dystrophy. PLoS One 7: e49083, 2012. PMID: 23185296. DOI: 10.1371/journal.pone.0049083

44 Borderie VM, Baudrimont M, Vallee A, Ereau TL, Gray F and Laroche L: Corneal endothelial cell apoptosis in patients with Fuchs' dystrophy. Invest Ophthalmol Vis Sci 41: 2501-2505, 2000. PMID: 10937560.

45 Engler C, Kelliher C, Spitze AR, Speck CL, Eberhart CG and Jun AS: Unfolded protein response in fuchs endothelial corneal dystrophy: A unifying pathogenic pathway? Am J Ophthalmol 149: 194-202, 2010. PMID: 20103053. DOI: 10.1016/j.ajo. 2009.09.009

46 Joyce NC: Proliferative capacity of the corneal endothelium. Prog Retin Eye Res 22: 359-389, 2003. PMID: 12852491.

$47 \mathrm{Li}$ QJ, Ashraf MF, Shen DF, Green WR, Stark WJ, Chan CC and O'Brien TP: The role of apoptosis in the pathogenesis of Fuchs endothelial dystrophy of the cornea. Arch Ophthalmol 119: 1597-1604, 2001. PMID: 11709009.

Received February 28, 2019

Revised March 24, 2019

Accepted March 26, 2019 